\title{
СОЦИАЛЬНО-КУЛЬТУРНЫЕ УСЛОВИЯ РАЗВИТИЯ ТВОРЧЕСКОГО ПОТЕНЦИАЛА ПОДРОСТКОВ В ДЕЯТЕЛЬНОСТИ ШКОЛЬНОГО ТЕАТРАЛЬНОГО КОЛЛЕКТИВА
}

\section{SOCIO-CULTURAL CONDITIONS FOR THE DEVELOPMENT OF THE CREATIVE POTENTIAL OF ADOLESCENTS IN THE ACTIVITIES OF THE SCHOOL THEATER GROUP}

M. Gurenko

Summary: The inclusion of teenagers in theatrical activities has a rich range of opportunities for the development of creative abilities: it develops the makings and creative qualities. The development of the creative potential of the individual is a continuous, purposeful process of actualization of personal capabilities, mechanisms of self-development and self-realization with the dominant role of the formation of the creative orientation of the individual. Therefore, it is important to study the socio-cultural school theater group. To do this, the author attempts to define the concept of "creative abilities". Work was carried out to identify the structural components of human creativity. The possibilities of theater pedagogy in the development of creative abilities of teenagers were also identified. And since personality is formed in adolescence, the features of adolescence that affect the development of creative abilities were considered. After that, the author characterized the sociocultural working conditions of the theater circle, which contribute to the development of creative abilities of teenagers. The conclusion of this work can be considered that the education of creative abilities of adolescents will be effective only if it is a purposeful process, during which a number of socio-cultural tasks are solved, aimed at achieving the final goal.

Keywords: creative abilities, creative potential, adolescence, theatrical activity, school theater group, artistic perception, development of special skills.

\author{
Гуренко Максим Владимирович \\ аспирант, ФГБОУ ВО «Тамбовский государственный \\ университет имени Г.Р. Державина», г. Тамбов \\ maxsimum14@mail.ru
}

Аннотация: На сегодняшний день много подростков включены в театральную деятельность. Это дает возможность развивать их творческие способности, развивать задатки и ряд творческих качеств. Такие процессы должны быть непрерывными и целенаправленными. Поэтому важным является изучение социально-культурных условий развития творческого потенциала подростков в деятельности школьного театрального коллектива. Для этого автором предпринята попытка определения понятия «творческих способностей» в целом и подростков, в частности. Была проведена работа по выявлению структурных компонентов творческих способностей человека. Также были обозначены возможности театральной педагогики в развитии творческих способностей подростков. И так как в подростковом возрасте формируется индивидуальность, была составлена характеристика подросткового периода, особенности которого оказывают влияние на процесс формирования и развития творческих способностей. Далее автор попытался охарактеризовать ряд социально-культурных условий работы подросткового театрального коллектива, которые могут оказывать непосредственное влияние на проявление творческих способностей. Выводом данной работы можно считать утверждение, что на эффективность развития творческих способность подростков оказывает влияние целенаправленность процесса, посредством которого может быть решен ряд социально-культурных задач, которые направлены на достижение конечной цели. Поэтому важным является изучение социально-культурных условий развития творческого потенциала подростков в деятельности школьного театрального коллектива.

Ключевые слова: творческие способности, творческий потенциал, подростковый возраст, театральная деятельность, школьный театральный коллектив, художественное восприятие, освоение специальных умений.

Под творческими способностями понимают ряд способностей человека, порождающие что-то новое качественно, ранее не существовавшее.

Уже не первый год специалисты решают вопрос раскрытия творческих способностей человека, которые являются основой эстетического восприятия окружающей действительности, создания абстрактных произведений искусства и символических предметов. Творческие способности изначально присущи каждому человеку, которые нужно лишь суметь раскрыть как можно раньше.

Творческие способности рассматриваются в качестве синтеза индивидуальных, психологических и физиче- 
ских особенностей личности на фоне процессов трансформации качественного состояния.

Под трансформацией качественного состояния принимается изменения в мышлении, восприятии, взгляде на собственную жизнедеятельность, изменения в мотивационной сфере. Данного рода трансформации могут возникать при реализации новой для человека деятельности, в процессе которой он решает новые задачи, проблемы. Это. В свою очередь, обуславливает успешность при выполнении новой деятельности, благодаря которой может появиться новый продукт, идея, предмет, художественное произведение и т.д.

Творческими способностями наделен каждый человек. Благодаря участию человека в конкретном виде деятельности такие способности могут проявляться, формироваться и развиваться.

Творческие способности, как и все окружающее человека, имеют собственную структуру, понимание которой обуславливает наличие необходимых знаний для того, чтоб организовать работу по развитию творческих способностей.

Специалисты так и не пришли к единому мнению относительно структуры творческих способностей. Но структуру творческих способностей подростков можно представить следующим образом:

- наличие когнитивного и эмоционального компонента. Сюда относят дивергентное мышление, темперамент с его особенностями, экспрессивность, чувствительность, эмоциональность и т.д.

- наличие компонента личностно-креативного характера. Сюда относится проявление творческого потенциала, наличие воображения, способность к критике, независимость, желание рисковать, проявление интеллектуальной активности,

- наличие мотивационного и ценностного компонентов. Это проявляется в потребности в творчестве, наличии мотивов деятельности общественного значения, признание важности и ценности творчества и т.Д.,

- присутствие деятельностного и процессуального компонента. Здесь имеются ввиду наличие творческой самостоятельности, способности оптимизировать собственное поведение,

- наличие рефлексивного компонента, представленного возможностью оценить собственную творческую деятельность, стремление самообразовываться, саморазвиваться и т.д.

Структурные компоненты творческих способностей подростков - часть единого целого. Они могут быть взаимовлияемыми и взаимопроникаемыми. Это говорит о «раскрытии» содержания каждого компонента посредством взаимодействия с остальными, проявления в них.
Творческие способности можно отнести к составляющим элементам артистизма в общем, как и составной части структуры индивида. Развитие их способствует развитию любого индивида в целом. И чем раньше начать это развитие, тем успешнее и плодотворнее разовьется личность.

Театральная деятельность направлена на развитие и усиление эмоций подростка. Благодаря театральной деятельности развивается воображение, фантазии, образное мышление. Также при реализации театрализованной деятельности подросток может преодолеть такую характерную для этого возраста психологическую зажатость.

Участие в занятиях театрального коллектива дает возможность подростку сформировать собственные актерские навыки, сделать собственные движения более пластичными, развить сценическую речь.

Театр обладает мощными средствами воспитания и развития людей. Это и привлекало внимание деятелей культуры, просвещения, педагогов-практиков. Театральное искусство - искусство синтетического характера. Театр воздействует на зрителя посредством звучащего слова, действия, пластики актеров, цветовым, световым и музыкальным решением сценического пространства и т.д. Благодаря свойству синтетичности театральное искусство обладает многосторонностью воздействия на зрителя.

Наверное, поэтому театр для подростков всегда ассоциируется с праздником, которые дарит яркость, незабываемость впечатлений. Также стоит отметить влияние в плане воспитания, обучения. Все это является чем-то важным для подростков, в частности, который начинает свой артистический путь.

В наши дни школьному театру отведено важное место в системе разностороннего воспитания современных подростков. Школьный театр сегодня - драматический, кукольный, театр теней, различные формы школьной театральной самодеятельности, игры, драматизации, драмкружки, студии и т.д. Более того, театральная деятельность представлена рядом искусств, к которым относится литература с драматическим произведением в качестве основы спектакля; искусством действенного и звучащего слова.

Сценическому искусству можно дать характеристику коллективности. Это обусловлено наличием зрителей и способности проявления таких сильных чувств, как коллективных переживаний, сила которых влияет на потребность обмена мнениями о том, что человек пережил, увидел. Это является очень важным при рассмотрении театра в качестве средства воспитания творческих начал в подростке. 
Подростковый возраст - период развития теоретического рефлексивного мышления. В этом возрасте подросток оперирует гипотезами, решая творческие задачи: при возникновении новой проблемы подросток пытается отыскивать разнообразные варианты решения таковой; находить применение абстрактным правилам, способным помочь в решении совокупности задач, что может являться свидетельством высокого потенциала развития способности к переносу опыта.

В структуре же художественных творческих способностей воображение играет главенствующую роль: подростки становятся более инициативными и самостоятельными, они пытаются сформулировать независимые высказывания и мнения. Нередко из-за этого стремления обнаруживается, что ученики уже не хотят получать знания в готовом, «разжеванном виде».

Подобное стремление наиболее благоприятная особенность для развития творческой активности подростков, направленности на творчество, и эти качества нередко ярко проявляются в этом возрасте в процессе учебной деятельности подростков.

Однако, стоит отметить и возникающие противоречия. Они тесно взаимосвязаны с особенностями развития психики подростка. К данного вида особенностям относится желание как быть похожими на сверстников, так и радикально выделяться на их фоне. Все это заставляет подростка признавать значимость собственного творчества, ценности результатов творческой деятельности.

Зачастую противоречия возникают и в процессе реализации театрализованной деятельности: реально признаваемая значимость результатов деятельности может иметь весомые отличия от желаемой, основанной исключительно на завышенной самооценке собственных действий. В качестве последствий этого может снижаться эффективность организации творческой деятельности подростков.

Но, несмотря ни на что, подростковый возраст является благоприятными для того, чтоб развивались творческие способности, однако же и имеющие специфические особенности.

Благодаря реализации театрализованной деятельности возможно решение множества социально-культурных задач: разнообразие тематики, возможность выбора средств изображения, эмоциональность театрализованной деятельности обуславливают ее использование для всестороннего и гармоничного развития личности, особенно в части развития ее творческих возможностей.

Подготовка к театрализованной деятельности требует решение ряда вопросов. И это заставляет подростка задействовать собственную мыслительную деятельность, проводить анализ сложных ситуаций, формулировать выводы, обобщать.

При работе над репликами персонажей должна задействоваться вся выразительность, активизироваться вся словарная активность, весь словарный запас, происходит совершенствование звуковой стороны речи. Тематика и содержание театрализованной деятельности зачастую направлена на формирование нравственности: подростку свойственно подражать полюбившемуся персонажу, он пытается перевоплотиться в него, жить его жизнью.

Театральная деятельность также способна формировать эстетический вкус человека, например, благодаря грамотному оформлению спектакля, декорациям, костюмам. При активном участии подростка в подготовке атрибутов и декораций развивается вкус, происходит эстетическое воспитание, что заставляет восхищаться прекрасным и негативно относится к отрицательному, тем самым заставляя нравственно и эстетически переживать, создавать определенное настроение, ощущать эмоциональный подъем, испытывать повышение жизненного тонуса подростков.

В заключении стоит отметить постоянные трансформации в нашей современной жизни: эпоха научно-технического прогресса делает нашу жизнь разнообразной и в то же время сложной, что отвергает шаблонные, привычные действия. От человека уже требуется подвижность, гибкость мышления, быстрота и резкость ориентации, адаптация ко вновь меняющимся условиям, и, самое главное, творческого решения возникающих проблем.

И даже учитывая то, что умственный труд теперь вытесняет физический, а весомая доля исполнительской деятельности становится автоматизированной, становится понятно, что творческие способности человека наиболее существенная часть интеллекта человека, что обуславливает важность решения задач современного воспитания подрастающего поколения. Объяснение всему этому - результатом творческой деятельности человека, который накоплен человечеством являются культурные ценности, а то, насколько будет продуктивно развиваться человечество в дальнейшем, оказывает непосредственное влияние творческого потенциала подрастающего поколения.

Эффект от воспитания творческих способностей подростков будет очевидным при условии целенаправленности процесса, при реализации которого возможно решение ряда социально-культурных задач, которые направлены на достижения конечной цели - формирование творческого потенциала подростков. 


\section{ЛИТЕРАТУРА}

1. Акимов И. 0 природе подросткового таланта / И. Акимов, В. Клименко. М. : Мол. гвардия, 2015. - Т. 1. - 224 с

2. Баринова М.Н. О развитии творческих способностей человека в разном возрасте / М.Н. Баринова. Л.: Музгиз, 2016. - 60 с.

3. Басин Е.Л. Психология художественного творчества и творческого потенциала / Е.Л. Басин. М.: Знание, 2018. -с. 64

4. Гуревич К.М. Лабиринты развития таланта ребенка-взрослого/ К.М. Гуревич // Искусство в шк. М., 2019. - № 1. - С. 48-53.

5. Каратыгин В.Г. Восторг творчества - восторг театра/ В.Г. Каратыгин // Муз. жизнь. М., 2020. - № 1. - С. 27-31.

6. Котова Е.В., Кузнецова С.В., Романова Т.А. Развитие творческих способностей учеников: Методическое пособие. М.: ТЦ Сфера, 2020. - 128 с.

7. Лапшина А.В. Взгляды на понятие «творчество» и его различные трактовки // Молодой ученый. - 2019. - Т.1. - С. $252-254$

8. Мудрик А.В. Личность школьника и её воспитание в коллективе / А.В. Мудрик. М.: Знание, 2018. - 96 с.

9. Николко В.Н. Творчество как инновационный процесс (Философскоонтологический анализ). - Симферополь: «Таврия», 1990. - 190 с

10. Пономарев Я.А. Исследование творческого потенциала человека / Я.А. Пономарев // Психол. журн. М., 2019. - Т. 12, № 1. - С. 3 - 11.

11. Развитие творчества и становление личности подростка. -Воронеж.: МШПО, 2019. 67 с.

12. Шадриков В.Д. Способности человека. - М., Институт практической психологии, 2017. - 288 с.

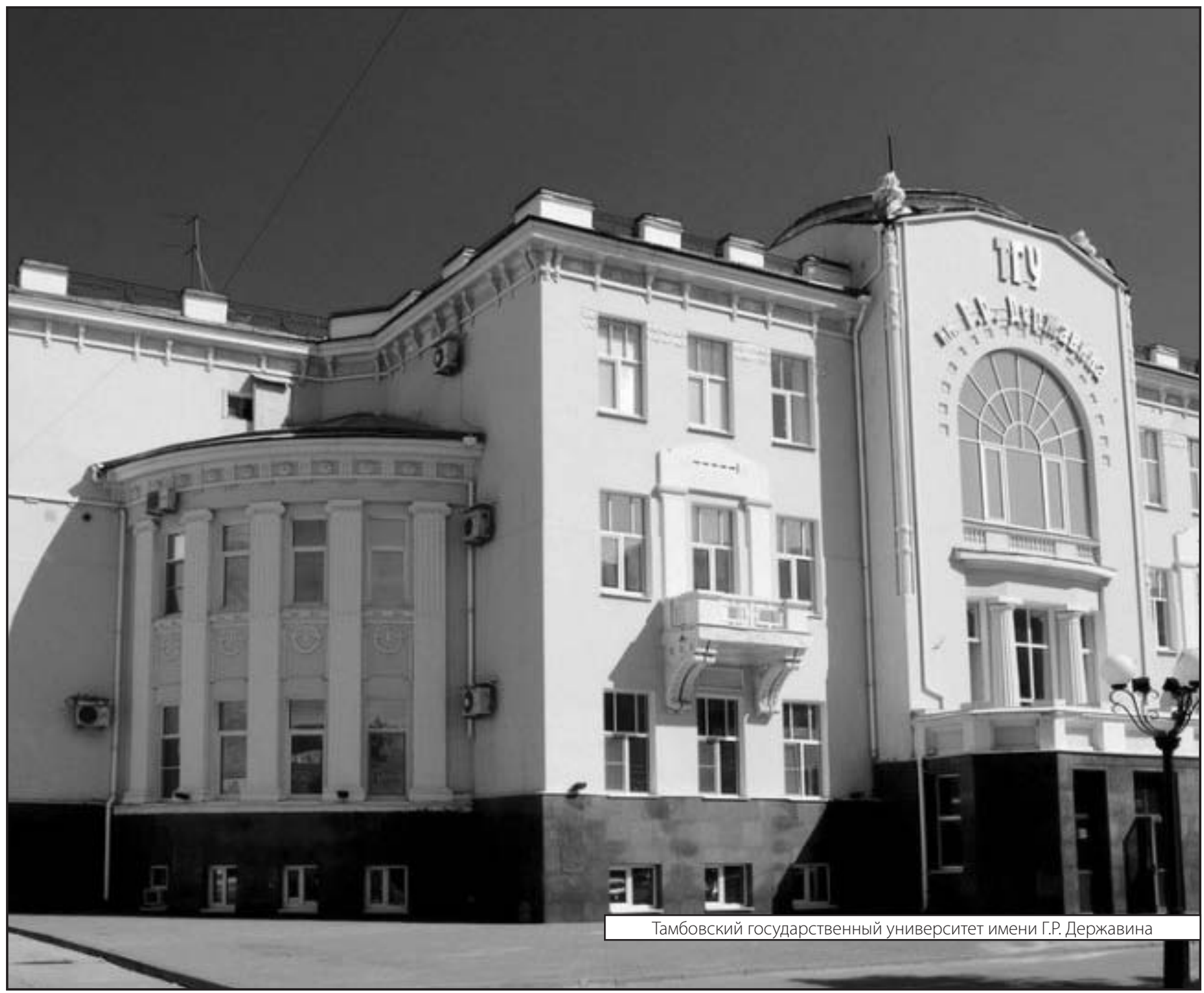

